\title{
PENGARUH KEPEMIMPINAN PELAYAN DAN IKLIM ORGANISASI TERHADAP KINERJA PELAYANAN PUBLIK PEGAWAI NEGERI SIPIL PADA PEMERINTAH KOTA BEKASI
}

\author{
Rony Setiawan, Suryana Sumantri, Tb. Zulrizka Iskandar, Marina Sulastiana \\ STIA Mandala Indonesia \\ email korespondensi: ronykusetia@gmail.com
}

\begin{abstract}
Abstrak
Faktor-faktor yang diduga terkait dengan rendahnya kinerja pelayanan publik adalah kecenderungan kepemimpinan pejabat publik yang tidak berorientasi pada pelayanan dan iklim organisasi yang kurang kondusif. Tujuan penelitian ini adalah untuk mengetahui pengaruh kepemimpinan pelayan dan iklim organisasi terhadap kinerja pelayanan publik. Penelitian kuantitatif eksplanasi kuantitatif ini menggunakan kuisioner yang disebarkan kepada 200 Pegawai Negeri Sipil pada Pemeritah Kota Bekasi yang diperoleh melalui teknik sampling random stratifikasi. Penelitian ini menemukan adanya pengaruh yang positif signifikan kepemimpinan pelayan dan iklim organisasi terhadap kinerja pelayanan publik dan pengaruh kepemimpinan pelayan terhadap kinerja pelayanan publik melalui iklim organisasi.
\end{abstract}

Kata kunci : Kepemimpinan Pelayan, Iklim Organisasi, Kinerja Pelayanan Publik, dan Pegawai Negeri Sipil Kota Bekasi

\begin{abstract}
The factors thought to be related to the low performance of public service leadership was the tendency of public officials who were not service-oriented and less conducive organizational climate. The purpose of this study was determined the effect of servant leadership and organizational climate on the performance of public services. This quantitative explanation of quantitative research using questionnaires technique distributed to 200 Civil Servants to the Government of Bekasi City through stratified random sampling technique. This study found out a significant positive effect of servant leadership and organizational climate on the performance of public service and the effect servant leadership on the performance of public services through organizational climate.
\end{abstract}

Keywords : Servant Leadership, Organizational Climate, Performance Public Service, and the Civil Service Bekasi City

\section{PENDAHULUAN}

Fenomena pelayanan publik yang belum optimal di hampir seluruh daerah di Indonesia menjadi permasalahan yang akan terus bergulir seiring dengan fakta yang terjadi dalam masyarakat dimana rumitnya alur birokrasi dan aparatur publik kurang berorientasi pada pelayanan kepada masyarakat.

Hal tersebut didasarkan pada hasil penelitian yang memaparkan belum optimalnya kinerja pelayanan aparatur pemerintah antara lain hasil analisis dari Word Bank, 2003-2013; The World Competitiveness Report, 2010-2012; Tim Kajian Kinerja Otonomi Daerah LAN, 2011; Harahap, 2011; Ombudsman Republik Indonesia, 2012 dan masih banyak yang lainnya. Secara mickro, peneliti juga melakukan kajian di Kota Bekasi dan dari hasil survei peneliti (2012) tentang kinerja pelayanan di kalangan internal sebanyak 30 PNS diperoleh hasil kualitas pelayanan pegawai di Kota Bekasi juga belum optimal.

Berdasarkan hasil kajian peneliti setidaknya ada dua faktor utama yang terkait dengan kinerja pelayanan publik yakni kepemimpinan dan iklim organisasi. Salah satu ciri kepemimpinan yang paling mendekati kesesuaian dengan fenomena yang terjadi pada kinerja pelayanan publik terutama pada birokrasi pemerintah adalah kepemimpinan pelayan. Hasil survey peneliti (2013) menunjukkan bahwa pemilihan pejabat publik di beberapa daerah di Jawa Tengah termasuk di Kota Bekasi belum didasarkan pada transparansi dan kompetensi serta cenderung lebih berorientasi pada diri sendiri maka diduga pejabat publik tersebut akan sulit memberikan pelayanan kepada orang lain sebagai prioritas yang utama.

Selain itu berdasarkan dalam survey yang berbeda peneliti (2013) juga menemukan suasana yang terjadi dalam birokrasi pemerintah di Kota Bekasi seperti suasana kekeluargaan, keadilan dalam berkarier dan kesejahteraan, transparansi anggaran dan yang lainnya masih belum menjadi agenda penting dalam pemerintahan. Adanya kelompok-kelompok primer dalam pemerintahan mendapat perlakuan yang berbeda-beda sehingga memunculkan suasana dalam organisasi yang kurang kompetitif, terutama keberpihakan rezim (pimpinan) yang berkuasa pada kelompok tertentu. Selain itu dari aspek birokrasi, adanya tumpang tindih tupoksi yang diperkuat dengan kurangnya koordinasi antar instasi membuat banyak pekerjaan saling bertubrukan dan banyaknya aturan terutama dari tingkat pusat yang silih berganti membuat proses implementasi juga mengalami kedala di lapangan, karena suatu kebijakan belum sempurna dipahami sudah muncul kebijakan lain, akibatnya menimbulkan kebingungan dalam implementasinya.

Berdasarkan uraian tersebut maka peneliti ingin mengkaji lebih dalam pengaruh kepemimpinan pelayan dan iklim organisasi terhadap kinerja pelayanan publik. Keunikan dalam penelitian ini, peneliti ingin membandingkan dan menggabungkan antara teori kepemimpinan pelayan yang berasal dari pemikiran Barat dengan kearifan budaya lokal terhadap kinerja pelayanan publik. 


\section{TINJAUAN TEORI}

\section{Kepemimpinan Pelayan}

Servant leadership pertama kali digagas oleh Greenleaf (1970), kemudian dikembangkan oleh para peneliti lain diantaranya adalah Spears (1995) yang mendefinisikan servant leadership sebagai sebuah jenis baru dari model kepemimpinan yang melayani orang lain sebagai prioritas pertama. Perkembangan karakteristik kepemimpinan pelayan mengalami kemajuan yang cukup pesat, banyak peneliti mencoba mengembangkan dimensi terutama dalam pengukuran kepemimpinan pelayan, diantaranya adalah Spears (1995, 2005) dengan 10 dimensi, Laub (1999) dengan 6 aspek, Russel dan Stone (2001) dengan 9 aspek, Patterson (2003) dengan 7 aspek, Page \& Wong (2003) dengan 8 aspek, Barbuto \& Wheeler (2006) dengan 5 aspek dan Sendjaya et al (2008) dengan 6 aspek.

Banyak peneliti mengingatkan untuk tidak serta merta menggunakan teori kepemimpinan pelayan yang berasal dari pemikiran dunia Barat ke dunia Timur karena adanya perbedaan kebiasaan dan latar budaya (Maruyama dalam Sedarmayanti, 2009; Hanzaee dan Mirvaisi, 2011; Barnabas dan Clifford, 2012). Oleh karena itu peneliti tidak sepenuhnya menggunakan teori kepemimpinan dari pemikiran Barat tetapi mencoba mengkaji dan membandingkan dengan kepemimpinan yang berasal dari kearifan budaya lokal bangsa Indonesia. Berdasarkan hasil kajian secara tidak terduga banyak sekali ditemukan persamaan ciri-ciri atau aspek-aspek kepemimpinan dari pemikiran Barat dengan kepemimpinan yang berbasis pada kearifan lokal.

Tabel di bawah, menunjukkan bahwa konsep kepemimpinan di manapun keberadaannya cenderung menunjukkan karakteristik yang sama, setidaknya ada 11 karakteristik/ciri kepemimpinan pelayan yang hampir sama dan 1 ciri yang berbeda, yaitu spirituality. Spirituality merupakan salah satu ciri kepemimpinan yang berbasis pada kearifan lokal, dimana ciri ini telah mampu menghantarkan kerajaan dan/atau negara yang dipimpinnya ke jaman keemasan. Hal ini karena spirituality membuat pemimpin akan mampu menahan diri dan dapat berbaur srta menyelami perasaan orangorang yang dipimpinannya.

Berdasarkan kajian teori tersebut akhirnya diperoleh 12 dimensi untuk mengungkap variabel kepemimpinan pelayan yaitu humility, vision, wisdom, listening, trust, love, persuasion development of people, healing, modeling, community building and spirituality.

\section{Iklim Organisasi}

Berdasarkan berbagai pendapat tentang iklim organisasi, seperti pendapat tetang lingkungan kerja (Gibson, et al, 1987), kualitas lingkungan internal organisasi memengaruhi sikap dan perilaku (Gilmer, 1966; Litwin, 1968, Rafferty, 2003; Simamora, 2004), pola perilaku, sikap dan perasaan terhadap dalam lingkungan sehari-hari (Isaksen dan Lauer, 1999), kepribadian sebuah organisasi (Davis dan Newstrom, 2001) dan Pines (1982) sebagai satu set persepsi
Tabel. 1 - Persamaan Ciri-ciri Servant Leadership dari Pemikiran Barat dengan Kepemimpinan yang Berbasis pada Kearifan Lokal Bangsa Indonesia

\begin{tabular}{|c|c|c|}
\hline $\mathrm{ba}$ & Persamaan Ciri Kepemimpinan & Nama Peneliti \\
\hline \multirow[t]{2}{*}{1} & Humility & $\begin{array}{l}\text { Graham(1991), Paterson (2003), Sendjaya et al. } \\
(2008)\end{array}$ \\
\hline & $\begin{array}{l}\text { Sikap rendah hati/tidak sombong, lemah } \\
\text { lembut (sariawa upasama) dan karakter air. }\end{array}$ & Gajah Mada, Asta Brata, Prabu Siliwangi \\
\hline \multirow[t]{3}{*}{2} & Wisdom & 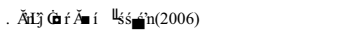 \\
\hline & Sikap sabar dan bijaksana (wijava, kearifan) & Gajah Mada, Pancasila, Prabu Siliwangi \\
\hline & Mulat sariro hangroso wani (selaras pikiran & Tri Brata \\
\hline \multirow[t]{4}{*}{3} & Vision, Visioning & Spears $(1995,2010)$, Patterson (2003); Page dan \\
\hline & Foresight & $\begin{array}{l}\text { Wong (2000); Laub (1999), Nabi Muhammad, } \\
\text { SAW }\end{array}$ \\
\hline & The providing of leadership, fathonah (cerdas) & Gajah Mada, Asta Brata, Sutan Agung dan \\
\hline & $\begin{array}{l}\text { Wicaksaneng naya, karakter bintang, swadana } \\
\text { maharjeng tursita, keahlian perang }\end{array}$ & $\begin{array}{l}\text { Prabu Siliwangi } \\
\text { Pat }\end{array}$ \\
\hline \multirow[t]{2}{*}{4} & Listening, empathy & $\begin{array}{l}\text { Spears }(1995,2010) \text {, Russell dan Stone (2002) } \\
\text { Laub }(1999)\end{array}$ \\
\hline & Value people & Graham(1991) \\
\hline \multirow[t]{4}{*}{5} & & Russell dan Stone (2002) danPatterson (2003) \\
\hline & Amanah (dapat dipercaya) & dan Muhammad, SAW \\
\hline & Stewardship (dipercava orang lain) & Spears $(1995,2010)$ \\
\hline & 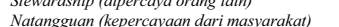 & Asta Brata \\
\hline 6 & $\begin{array}{l}\text { latangguan (kepercayaann arar masyarakat) } \\
\text { Love, mencintai dan dicintai (sih samasta } \\
\text { bhuwana) }\end{array}$ & $\begin{array}{l}\text { Greenleaf (1977), Patterson (2003), Gajah Mada, } \\
\text { Prabu Sliwangi }\end{array}$ \\
\hline 7 & Persuasion & $\begin{array}{l}\text { Spears (1995, 2010), Russell dan Stone (2002), } \\
\text { Barbuto dan Wheeler (2006) }\end{array}$ \\
\hline \multirow[t]{2}{*}{8} & $\begin{array}{l}\text { Moral development, development of people, } \\
\text { commitment to the growth }\end{array}$ & $\begin{array}{l}\text { Russell dan Stone (2002), Page dan Wong (2000) } \\
\text { Graham (1991), Laub (1999), Spears (1995) }\end{array}$ \\
\hline & $\begin{array}{l}\text { Membangun motivasi dan kemauan : (karakter } \\
\text { matahari, tut wuri handayani) }\end{array}$ & Asta Brata, KH Dewantara, Pancasila, \\
\hline \multirow[t]{2}{*}{9} & Healing & Spears $(1995,2010)$, Barbuto \& Wheeler, 2006 \\
\hline & Karakter bulan (mengatasi cemas \& takut) & Asta Brata \\
\hline \multirow[t]{2}{*}{10} & Modeling & Russell dan Stone (2002) \\
\hline & $\begin{array}{l}\text { Menjadi panutan (sumantri, bahni bahna } \\
\text { amurbeng jurit ing nogrsa sung tulada }\end{array}$ & $\begin{array}{l}\text { Gajah Mada, Sultan Agung, KH Dewantara, } \\
\text { Pancasila \& Sultan Agung }\end{array}$ \\
\hline \multirow[t]{2}{*}{11} & $\begin{array}{l}\text { Community building } \\
\text {. }\end{array}$ & Spears $(1995,2010)$ \\
\hline & $\begin{array}{l}\text { Mengutamakan kepentingan negara (Nagara } \\
\text { gineng pratijna), karakter angin }\end{array}$ & Gadjah Mada, Asta Brata \\
\hline 12 & $\begin{array}{l}\text { Spirituality } \\
\text { Sols }\end{array}$ & $\begin{array}{l}\text { Asta Brata, Sultan Agung, Prabu Siliwangi, } \\
\text { Gadjah Mada, Pancasila dan Sendjaya dkk }\end{array}$ \\
\hline
\end{tabular}

individu terhadap lingkungan organisasi yang mampu memengaruhi motivasi anggota organisasi sehingga dapat berperilaku tertentu.

Berdasarkan berbagai pendapat di atas dapat disimpulkan bahwa iklim organisasi merupakan persepsi, sikap, perasaan baik secara individu maupun bersama-sama tentang suasana dalam organisasi yang memiliki pengaruh dan sekaligus menentukan cara berperilaku dalam organisasi.

Tabel 2 - Persamaan Unsur dalam Dimensi Iklim Organisasi

\begin{tabular}{|c|c|c|}
\hline No & Peneliti & Dimensi Iklim Organisasi \\
\hline \multirow[t]{6}{*}{1} & Litwin dan Stringer (1968) & tanggung jawab, motivational \\
\hline & Likert (1961), Moos (1974) & autonomy, task orientation, innovation \\
\hline & Pines (1982) & \\
\hline & Patterson et al (2005) & psychological (mental dan emosional) \\
\hline & Gupta (2008) & autonomy and pressure to product \\
\hline & Ekval (1996) & $\begin{array}{l}\text { competency and commitmen } \\
\text { freedom }\end{array}$ \\
\hline \multirow[t]{4}{*}{2} & Moos (1974) & physical comfort (kenyamanan fisik) \\
\hline & Tagiuri (1968) & ecology (fisik dan material) \\
\hline & Pines (1982) & structural (dependen dan independen) \\
\hline & Gupta (2008) & environment \\
\hline \multirow[t]{8}{*}{3} & Litwin dan Stringer (1968) & dukungan dan komitmen \\
\hline & Likert (1961) & interaction-influence \\
\hline & Moos (1974) & $\begin{array}{l}\text { involvement, peer cohesion, supervisor support } \\
\text { millieu (dimensi sosial dalam organisasi) }\end{array}$ \\
\hline & Tagiur (1968) & social (interaksi semua orang yang terlibat) \\
\hline & Pines (1982) & human relations \\
\hline & Patterson et al (2005) & $\begin{array}{l}\text { positive peer group, supervision relations, } \\
\text { product emphasis participation }\end{array}$ \\
\hline & Gupta (2008), & team work, involvement \\
\hline & Ekval (1996) & challenge/involvement, trust \\
\hline \multirow[t]{7}{*}{4} & Litwin dan Stringer (1968) & \\
\hline & Likert (1961) & karyawan), decision making, goal setting and \\
\hline & Moos (1974) & control (pengendalian), managerial control \\
\hline & Tagiuri (1968) & 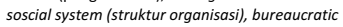 \\
\hline & Pines (1982) & (organisasi dan birokrasi) \\
\hline & Patterson et al (2005) & organizational goals \\
\hline & Hunter et.al, Gupta (2008) \&Ekval (1996) & $\begin{array}{l}\text { organisational integration, risk-taking, } \\
\text {, }\end{array}$ \\
\hline
\end{tabular}

Berdasarkan berbagai model iklim organisasi yang disampaikan oleh para peneliti (lihat tabel 2) maka untuk menentukan dimensi yang digunakan untuk mengungkap variabel penelitain dikaitkan dengan kesesuaian dimensi dengan subyek penelitiannya. Penelitian ini menggunakan subyek pegawai negeri sipil pada Pemerintah Kota Bekasi maka menurut peneliti dimensi dari Pines (1982) dipandang memiliki persamaan iklim organisasi dengan dunia birokrasi pemerintah. Selain itu berbagai dimensi yang telah 
ditunjukkan dalam tabel 2 di bawah. Untuk itu peneliti menggunakan dimensi dari Pines (1982) yang terdiri dari psychological, structural, social, and bureaucratic untuk dipilih menjadi dimensi yang digunakan untuk mengungkap variabel iklim organisasi.

\section{Kinerja Pelayanan Publik}

Ada dua hal penting yang berperan dalam pelayan yakni subyek yang melayani dan obyek yang dilayani. Melayani dan dilayani adalah prsoses pelayanan dimana telah terpenuhinya kebutuhan kedua belah pihak, disatu sisi bagi yang melayani akan terpenuhinya tugas melayani (bagian dari pekerjaannya) dan dari sisi yang dilayani terjadi kepuasan atas kebutuhan yang terpenuhi (Parasuraman, Zeithaml dan Berry, 1985; Lewis dan Mitchell, 1990, dalam Shahin, 2001). Sejalan dengan hal itu Gronroos (1991) juga menyebutkan bahwa pelayanan dirasakan sebagai hasil dari suatu proses evaluasi, di mana pelanggan membandingkan harapan mereka dengan layanan yang mereka telah menerima (dalam Suroja, 2003; Scheider dan White, 2004). Berdasarkan uraian di atas, maka kinerja pelayanan publik dalam penelitian ini dapat diartikan sebagai proses dan hasil perilaku yang dilakukan oleh lembaga pemerintah (penyelenggara pelayanan publik) untuk memenuhi kebutuhan publik (masyarakat) secara profesional, berkualitas dan memuaskan baik secara langsung maupun tidak langsung dalam bentuk administratif, barang dan jasa sesuai dengan aturan pokok dan tata cara yang telah ditetapkan

Teori service quality (servqual) dianggap sebagai metode yang paling umum untuk mengukur kualitas layanan (Kang dan Alexandris, 2002; Dixon, Napolitano \& Hogskola, 2005; Ravichandran, et all, 2010). Menurut Parasuraman, Zeithaml dan Berry (1991), model Servqual secara luas telah digunakan pada setiap organisasi jasa untuk memahami persepsi pelanggan mengenai kebutuhan layanan mereka (Ravichandran et al, 2010, Hirmukhe, 2012). Berdasarkan hasil kajian awal, peneliti menambahkan dua dimensi lagi dari lima dimensi Servqual yang ada, yaitu ketrampilan (skill) dan komitmen terhadap aturan. Hal ini dikarenakan banyaknya kritik terhadap teori Servqual (Gummesson, 1992; Buttle, 1996; Brady dan Cronin, 2001; Karen dan Boo, 2007).

\section{Hipotesis}

Hipotesis yang diajukan dalam penelitian ini adalah :

$\mathrm{H}_{11}$; Ada pengaruh yang signifikan antara kepemimpinan pelayan terhadap kinerja pelayanan publik pegawai negeri sipil pada Pemerintah Kota Bekasi.

- $\mathrm{H}_{12}$; Ada pengaruh yang signifikan antara iklim organisasi terhadap kinerja pelayanan publik pegawai negeri sipil pada Pemerintah Kota Bekasi.

\section{METODE}

Penelitian ini berjenis penelitian eksplanasi dengan pendekatan kuantitatif. Populasi penelitian ini adalah seluruh pegawai negeri sipil (PNS) di lingkungan Pemerintah Kota Bekasi yang dibatasi pada bidang yang menyelenggarakan pelayanan langsung kepada masyarakat, sehingga jumlah populasi targetnya sebanyak 3.154 orang. Teknik sampel yang digunakan adalah teknik sampling stratifikasi sebanyak 200 orang yang tersebar dalam 38 SKPD.

Kuisioner sebagai alat pengumpul data menggunakan data ordinal 5 poin (sangat sesuai $\mathrm{s} / \mathrm{d}$ sangat tidak sesuai). Variabel kepemimpinan pelayan diungkap melalui 12 dimensi, variabel iklim organisasi diungkap melalui 4 dimensi, sedangkan variabel kinerja pelayanan publik diungkap melalui 7 dimensi. Teknik analisis data menggunakan SEM (Structural Equation Model) dengan batuan Lisrel 8,7 untuk mengetahui model pengukuran dan model struktural.

Tabel 3 - Profil Demografi dari Responden Penelitian

\begin{tabular}{cccccc}
\hline Variabel & $\mathrm{N}$ & $\%$ & Variabel & $\mathrm{N}$ & $\%$ \\
\hline \hline Usia & & & Masa Kerja & & \\
$18-30$ & 32 & 16 & $2-5$ & 22 & 11 \\
$30-40$ & 56 & 28 & $5-10$ & 44 & 22 \\
$40-50$ & 79 & 39,5 & $10-15$ & 45 & 22,5 \\
$\quad>50$ & 33 & 16,5 & $>15$ & 89 & 44,5 \\
Jenis Kelamin & & & & & \\
Laki-laki & 106 & 53 & Tingkat Pendidikan & & \\
Wanita & 94 & 47 & SMA & 28 & 14 \\
Jenjang Jabatan & & & D3 & 22 & 11 \\
Pelaksana & 105 & 52,5 & S1 & 95 & 47,5 \\
Eselon IV & 68 & 34 & S2 & 55 & 27,5 \\
Eselon III & 27 & 13,5 & & & \\
\hline & & & & &
\end{tabular}

Data demografi (tabel 3) menunjukkan bahwa responden lebih banyak berasal dari usia sangat produktif, yakni rentang usia 40-50 (39,5\%) dan didominasi laki-laki (53\%) daripada perempuan (47\%). Sedangkan dari jenjang jabatan mayoritas adalah pegawai pelaksana $(52,5 \%)$. Responden juga didominasi pegawai yang memiliki masa kerja di atas 50 tahun (44,5\%) dan ditinjau dari tingkat pendidikan maka jenjang S1 menduduki peringat terbanyak $(47,5 \%)$.

\section{HASIL DAN PEMBAHASAN}

\section{Analisis Model Pengukuran}

Berdasarkan analisis CFA dari jumlah 102 item variabel kepemimpinan pelayan menghasilkan data valid sebanyak 94 item (loading factors menunjukkan skor 0,38-0,87) dengan nilai-t di atas 4,9 (nilai t>1,96). Pada variabel iklim organisasi dari jumlah 45 item menghasilkan data valid sebanyak 37 item (koefisien loading factors menunjukkan skor antara 0,36-0,90) dengan nilai-t di atas 3,8 (nilai $t>1,96$ ). Sedangkan pada variabel kinerja pelayanan publik, dari 66 item diperoleh data valid sebanyak 56 item, dengan nilai koefisien loading factors menunjukkan skor diatas 0,37 dengan nilai-t di atas 3,30.

Berdasarkan nilai ukuran GOF (good of fit), dimana berdasarkan hasil perhitungan diperoleh nilai NFI, NNFI, CFI, IFI RFI dan GFI menunjukkan skor > 0,9, artinya nilai-nilai tersebut telah menunjukkan kecocokan model yang baik. Jadi masing-masing variabel teramati telah mampu merefleksikan variabel kepemimpinan pelayan, termasuk iklim organisasi kinerja pelayanan publik.

Tingkat reliabilitas alat ukur dilihat dari constract reliability $(\mathrm{CR})>0,7$ dan variance extracted $(\mathrm{VE})>0,5$ maka alat ukur katakan reliabel (Wijanto, 2008). Berdasarkan hasil perhitungan melalui CFA, diperoleh seluruh nilai variabel CR diatas 0,8 dan VE diatas 0,51 , sehingga dapat dikatakan bahwa alat ukur ketiga variabel memiliki tingkat validitas dan reliabilitas yang baik. 


\section{Analisis Model Struktural}

Pengukuran model struktural menunjukkan pengaruh di antara laten variables. Berdasarkan uji kecocokan keseluruhan model (GOF/Goodness of Fit) menunjukkan bahwa sebagian besar ukuran menunjukan kecocokan yang baik (RMSEA, GOF, NFI, $\mathrm{NNI}, \mathrm{CFI}, \mathrm{RFI}, \mathrm{RMR})$ sehingga kecocokan keseluruhan model antar variabel laten adalah baik.

Hubungan kausal dan koefisien determinasi antar variabel laten didasarkan hasil pada Tabel 4 dan Gambar 1, menunjukkan bahwa nilai-t dari koefisien kemimpinan pelayan sebesar 4,109 > 1,96 yang berarti koefisien pengaruh variabel kepemimpinan pelayan terhadap kinerja pelayanan publik sebesar 0,28 adalah signifikan. Koefisien korelasi ikllim organisasi terhadap kinerja pelayaan publik sebesar 0,42 ddengan nilai-t sebsesar 6,7i.

Jadi berdasarkan hasil tersebut maka Hipotesis Nihil (Ho) ditolak di kedua model pengaruh, artinya ada pengaruh yang signifikan antara variabel kepemimpinan pelayan terhadap kinerja pelayanan publik, dimana semakin tinggi kepemimpinan pelayan akan meningkatkan kinerja pelayanan publik. Iklim organisasi juga berpengaruh positif dalam meningkatkan kinerja pelayanan publik Pegawai Negeri Sipil di lingkungan Pemerintah Kota Bekasi.

Tabel 4 - Analisis Hubungan Kausal

\begin{tabular}{clcccc}
\hline No. & \multicolumn{1}{c}{ Jalur } & Estimasi & Nilai $-\mathrm{t}$ & $\mathrm{R}^{2}$ & Simpulan \\
\hline \hline 1 & $\begin{array}{l}\text { Kepemimpinan Pelayan (KP) } \\
\text { Kinerja Pelayanan Publik (KPP) }\end{array}$ & 0.28 & 2,059 & 0,0784 & Signifikan \\
2 & $\begin{array}{l}\text { Iklim Organiasi (IO) Kinerja } \\
\text { Pelayanan Publik (KPP) }\end{array}$ & 0,42 & 2,207 & 0,1764 & Signifikan \\
\hline
\end{tabular}

Ket : Signifikan bila nilai-t $>1,96$

Dimensi yang paling tinggi pengaruhnya membetuk kepemimpinan pelayan adalah dalah love $(0,81)$, persuasion $(0,81)$ dimana peserpsi pegawai terhadap kepemimpinan pelayan kepala SKPD (Satua Kerja Perangkat Daerah) didominasi ciri-ciri pemimpin yang welas asih, bersedia membantu dan menolong bawahan serta pemimpin yang mampu meyakinkan bawahan tanpa melalui paksaan atau tekanan. Selain itu dukungan nilai-nilai spirituality yang cukup kuat $(0,77)$, hal ini menunjukkan bahwa bangsa Indonesia khususnya pejabat di Kota Bekasi masih sangat menunjung tinggi nilai spirituality. Melalui pemimpin yang welas asih dan mampu meyakinkan bawahan tanpa paksaan denga didukung spirituality akan menguatkan kinerja pelayanan publik. Demikian pula dalam iklim organisasi yang kondusif dan menyenangkan dengan didukung aspek sosial $(0,90)$ yakni terjalinnya hubungan yang baik dengan sesama pegawai dengan atasan dan dengan pelanggan terbukti telah mampu meningkatkan persepsi pegawai bahwa kinerja mereka telah meningkat. Meperhatikan uji model pengaruh antar variabel menunjukkan model yang fit maka model kepemimpinan yang baik adalah kepemimpinan pelayan memengaruhi kinerja pelayanan publik melalui iklim organisasi, artinya kuatnya kepemimpinan yang dimiliki pejabat publik belum tentu meningkatkan kinerja pelayan publik selama iklim organisasinya kurang kondusif untuk bekerja. Oleh karena itu pimpinan perlu memperhatikan iklim organisasi yang menyenangkan bila ingin kinerja pelayanan publik para pegawainya meningkat. Namun selain itu pejabat publik juga perlu memunculkan kepemimpinan publik yang didukung dengan nilai-nilai spirituality, karena melalui aspek ini akan mempu memperkuat kepemimpinan pelayan dalam meningkatkan iklim organisasi dan kinerja pelayanan publik.

\section{SIMPULAN}

Berdasarkan hasil penelitian akhirnya dapat disimpulkan : 1) Ada pengaruh yang positif signifikan kepemimpinan pelayan terhadap kinerja pelayanan publik. 2) Ada pengaruh yang positif signifikan ikllim organisasi terhadap kinerja pelayanan publik. Love dan persuasion memiliki pengaruh terbesar dalam membentuk kepemimpinan pelayan yang didukung nilai-nilai spirituality. Iklim organiasi yang kondusif dibentuk oleh asek sosial. 3) Kepemimpinan pelayan juga berpengaruh terhadap kinerja pelayaan publik melalui iklim organiasi. 4) Penelitian ini membutktikan pentingnya iklim organisasi dalam birokrasi publik sehingga pemerintah perlu menciptakan iklim organisasi yang menyenangkan selain menerapkan atau mensyaratkan para pejabat publik untuk menampilkan kepemimpinan pelayan.

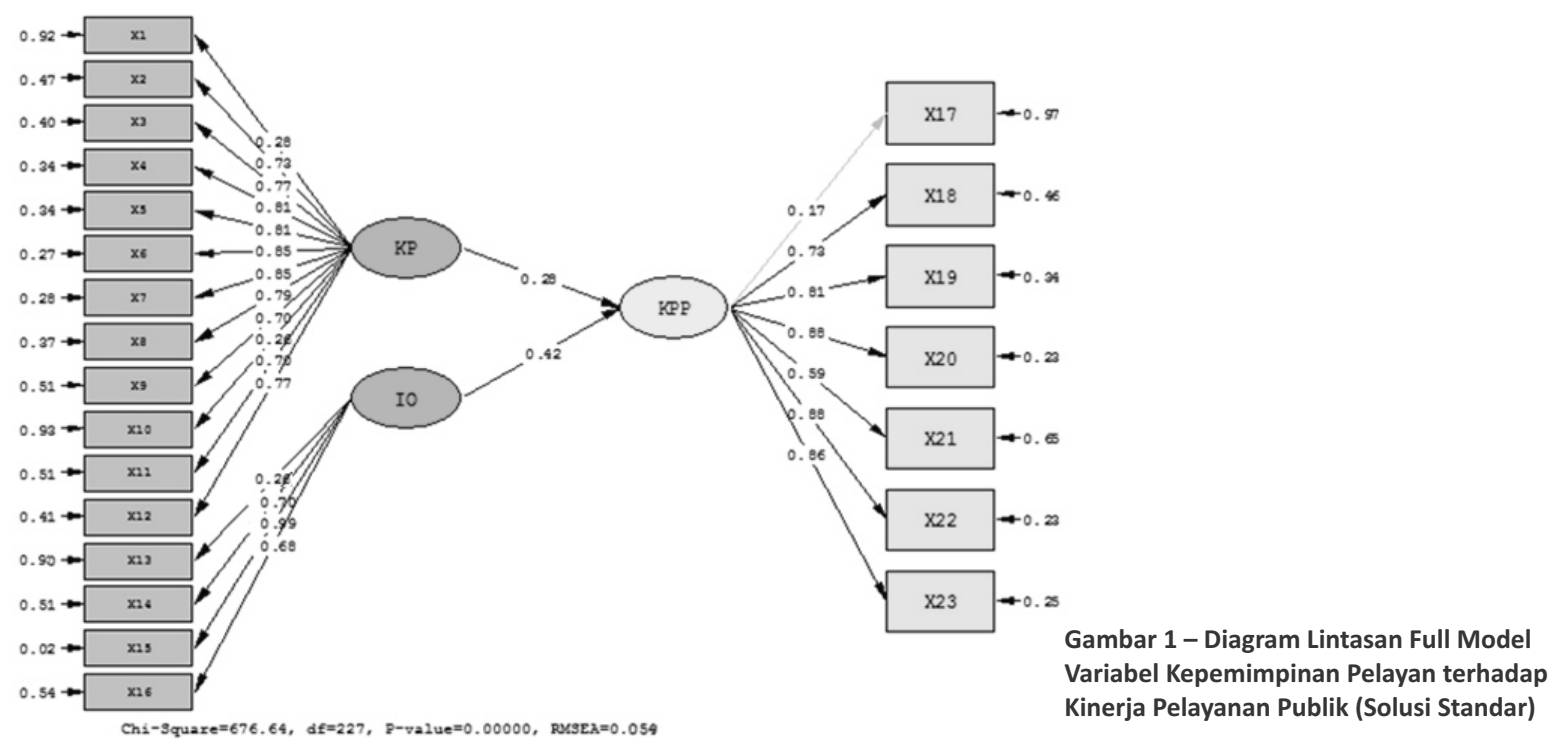




\section{DAFTAR PUSTAKA}

Azhar, Iqbal Nurul. 2011. Kepemimpinan Bangsa Dalam Paribasan Jawa (Aksioma Budaya Yang Mulai Ditinggalkan). Dipresentasikan pada Sidang Komisi E Kongres Bahasa Jawa V, Surabaya : 28-30 Nopember 2011.

Barnabas, A. \& Clifford, P.S. (2012). Mahatma Gandhi - An Indian Model of Servant Leadership. International Journal of Leadership Studies, Vol. 7 Iss. 2, pp. 132-150.

Barbuto, J.E., and Wheeler, D.W. (2006, June). Scale Development and Construct Clarifcation of Servant Leadership. Published in Group \& Organization Management 31: 3, pp. 300-326.

Dixon, Benn \& Napolitano, Alessandro. (2005). Service Quality In Relation To Tangibility. Thesis : Mälardalens Högskola for the degree of MIMA International Marketing.

Greenleaf, R.K. (1977). Servant leadership: A Journey into The Nature of Legitimate Power \& Greatness (25th Anniversary Ed.). Mahway, NJ: Paulist Press.

Harahap. Tri Rustiana. 2011. Studi Tentang Kualitas Pelayanan Publik (Studi Kasus KTP Di Kota Bekasi). Yogyakarta : Universitas Gadjah Mada.

Hanzaee, Kambiz Heidarzadeh dan Mirvaisi, Majid. 2011. Implementing Gronroos Service Quality Model: The Role of Image and Service Quality Perception on Customer Satisfaction in the Iran Hotel Industry. Journal of Basic and Applied Scientific Research J. Basic. Appl. Sci. Res., 1(11) 2482-2487 Text Road Publication

Laub, J. (1999). Organizational Leadership Assessment. Wellington, FL: Organizational Leadership Assess (OLA.).

Likert, Rensis (1961). New Patterns of Management. New York: McGraw Hiil Book Co

Moos, R. H. 1974. The Social Climate Scales: An Overview. Palo Alto, CA: Consulting Psychologist Press.

Parasuraman, A., Zeithaml, Valarie A. \& Berry, Leonard L. (1985). A Conceptual Model of Service Quality and Its Implications for Future Research Journal of Marketing Vol. 49, 41-50.

(1991). Refinement and reassessment

of The SERVQUAL scale. Journal of Retailing, Vol. 67 No. 4, pp. 420-50.

Patterson, K. (2003). Servant Leadership : A Theoretical Model. Servant Leadership Research Roundtable : Regent University.

Purwadi, Djoko Dwiyanto. 2006. Filsafat Jawa: Ajaran Hidup yang Berdasarkan Nilai Kebijaksanaan Tradisional. Yoyakarta : Panji Pustaka.

Ravichandran, K. et al. (2010). Influence of Service Quality on Customer Satisfaction Application of Servqual Model. International Journal of Business and Management. Vol. 5, No. 4; April 2010.

Russel, R.F. (2001). A Review of Servant Leadership Attributes : Developing a Practical Model. Leadership \& Organisational Development Journal : 145-157.

Sedarmayanti (2009), "Sumber daya Manusia dan Produktivitas Kerja". Bandung: CV. Mandar Maju.

Sendjaya, S. (2005). Servant Leadership : A Quiet Revolution in the Workplace. Newsletter of the MLQ Network. Volume 7 Issue 3. Article. Leadership Assessment \& Development Service.

Spears, Larry. C. (1995). Reflection on Leadership : How Robbert K. Green Leaf's Theory of Servant-leadership Influenced Today's Top Management Thinkers. New York : John Wiley and Sons. . (2005). Practicing Servant-Leadership. Hesselbein \& Company. Fall. Regent University : School of Leadership Studies.

Wijanto, Setyo Hari. 2008. Structural Equation Modelling dengan LISREL 8.8: Konsep dan Tutorial. Yogyakarta: Graha llmu.

Wong, P.T. \& Page, D. (2003). Servant Leadership: An Opponentprocess Model and The Revised Servant Leadership Profile. Regent University \& Trinity Western University: School of Leadership Studies.

Yasasusastra, J.S. (2011) Asta Brata : 8 Unsur Alam Simbol Kepemimpinan. Yogyakarta : Pustaka Mahardika. 